\title{
Proximal-distal facies relationships and sedimentary processes in a storm dominated carbonate ramp (Kimmeridgian, northwest of the Iberian Ranges, Spain)
}

\author{
B. Bádenas*, M. Aurell \\ Departamento Ciencias de la Tierra, Universidad de Zaragoza, 50009 Zaragoza, Spain
}

Received 13 January 2000; accepted 14 July 2000

\begin{abstract}
Facies analysis of the upper Kimmeridgian rocks in the outcrops located near Ricla (Zaragoza province, northeast Spain) and the integration of the resultant data in a broader context (the northern part of the Iberian Basin), has produced two general models showing the facies distribution and the processes that controlled the sedimentation in the Kimmeridgian carbonate ramp. Using these two models the transition from shallow to relatively deep environments of the carbonate ramp is examined in detail. Model 1 corresponds to the development of a mixed carbonate-siliciclastic ramp during a slow rise and stillstand of sea level (Sequence 1-HST), whereas Model 2 represents the growth of a pure carbonate ramp during a rapid rise of sea level (Sequence 2-TST).

Carbonate production was higher in the shallow ramp domains (coral reefs and oolitic shoals in Model 1 and reefs in Model 2) than in deeper domains, where there is no indication of significant pelagic or benthic production. The activity of unidirectional return flows induced by winter storms and hurricanes, played an important role in the redistribution of the sediment across the ramp, generating different coarse-grained deposits. In the inner and mid-ramp settings dunes, lower scale bedforms and tempestites occur in Model 1, and storm lobes, bars and tempestites in Model 2. Moreover, a significant bulk of the carbonate mud produced in shallow areas would eventually be resedimented in the outer ramp as suspended load in the density currents. Stillstand of sea level in Model 1 involved a rapid progradation of the inner and proximal mid-ramp carbonate and siliciclastic facies. The rapid relative sea level rise of Model 2 is determined by the dominance of the carbonate facies and by the presence of aggradational geometries in the transitional area between shallow and deep-ramp domains. The presence of relatively thick sections in the outer-ramp settings (instead of condensed sections, as observed in Model 1) during times of sea level rise (Model 2) can mainly be explained by the increase of the shallow production in the reef dominated areas. (C) 2001 Elsevier Science B.V. All rights reserved.
\end{abstract}

Keywords: Carbonate ramp; Iberian Ranges; Tempestite; Upper Jurassic

\section{Introduction}

The development of carbonate ramps on ancient

\footnotetext{
* Corresponding author. Fax: +34-976-761-088.

E-mail addresses: bbadenas@posta.unizar.es (B. Bádenas), maurell@posta.unizar.es (M. Aurell).
}

marine platforms was favoured during greenhouse periods. The associated elevated sea level caused the flooding of the interior of the continental areas, giving rise to epeiric seas. Shallow carbonate ramps developed in the interior continental areas that had a planar topography and gentle slopes. Despite their abundance in the sedimentary record, knowledge of the 
factors that controlled the sedimentation in ancient epeiric carbonate ramps is limited. This is mainly because of the absence of recent analogues, and the differences on the climatic condition and the oceanic circulation between the Holocene and the greenhouse periods (Burchette et al., 1990; Burchette and Wright, 1992; Aurell et al., 1995; Wright and Burchette, 1996).

The variation of carbonate production with depth is an important factor controlling the overall geometry and facies distribution in carbonate platforms. When rates of carbonate production are much higher in shallow water than in deep water, the development of rimmed-shelf platforms occurs (Schlager, 1981; Kendall and Schlager, 1981; Bosence et al., 1994). In contrast, when the carbonate sedimentation rates in shallow and deep domains is less differentiated, the development of carbonate ramps would be favoured (Wright and Faulkner, 1990). However, this model does not completely apply to the carbonate ramps that were developed in the Iberian Basin during the Kimmeridgian, which were dominated by ooid shoals and coral patch reefs in their shallow areas. In this case, the differential sedimentary rates between shallow and deep domains, could partly be compensated by a significant offshore transport of the carbonate produced in shallow areas (Aurell et al., 1995, 1998; Bádenas, 1999). The ramp model reported by these authors allows further discussion on the mechanisms and sedimentary processes that control the interaction between the high carbonate productivity shallow area, and the deep areas where carbonate mud accumulated. The transition area from shallow to relatively deep-ramp realms is the key-point to evaluate these sedimentary processes.

The continuous and nearly undeformed Upper Jurassic outcrops located near Ricla (northeast Spain: Fig. 1) provide a $7 \mathrm{~km}$ cross-section showing the transition between the shallow and relatively deep realm of the carbonate ramp which developed during the Kimmeridgian-early Tithonian in the Iberian Basin. Specifically, this transition can be studied in detail along two well-differentiated stages of evolution of the carbonate ramp, that belong to two different depositional sequences (Aurell et al., 1998, 2000; Bádenas, 1999): one developed during a stillstand of sea level (highstand systems tract, lower sequence), another developed during a rise of sea level (transgressive systems tract, upper sequence).
This paper has three objectives: (1) to present a description of the facies and their distribution on the Iberian Kimmeridgian carbonate ramp in the outcrops located near Ricla (Zaragoza); (2) to present the palaeoenvironmental reconstruction of the carbonate ramp during two successive stages of development; and (3) to propose and discuss two models showing the overall facies distribution and processes in the studied carbonate ramp in a broader context (the northern Iberian Basin).

\section{Palaeogeographic and palaeoclimatic setting}

The palaeogeographic setting during the Kimmeridgian in the northeastern part of the Iberian Plate is shown in Fig. 1. Sedimentation took place in extensive shallow-ramp settings (a few hundreds kilometres across) during the Late Jurassic. These were open to the Tethys Sea towards the east and temporarily connected with the boreal realm across the Soria Seaway to the northwest (Alonso and Mas, 1990; Aurell and Meléndez, 1993). The study area is located in the northwestern part of the Iberian basin (northeast Spain), in the transition area between the shallow and the relatively deep domains. Shallow-ramp areas were dominated by siliciclastic and ooid shoals and coralgal reefs, whereas the depth-ramp areas were the site of carbonate mud accumulation.

The general climatic conditions for the Jurassic have been reported as warm and humid, with a reduced temperature cycle and a low temperature gradient along latitudes (Valdes and Sellwood, 1992; Leinfelder, 1993). The climatic conditions, along with the distribution of the land areas and oceans during the Kimmeridgian, favoured the development of hurricanes. According to Marsaglia and Klein (1983), the shallow areas located in northern and western Europe had a mixed influence of hurricanes and winter storms. These authors propose a northwest pathway for the hurricanes that affected the shallow areas of the Iberian basin. Moreover, according to proposed circulation models for the Kimmeridgian (Price et al., 1995), the ramps developed in the Iberian basin had a windward aspect with respect to the winter winds (Fig. 1). 


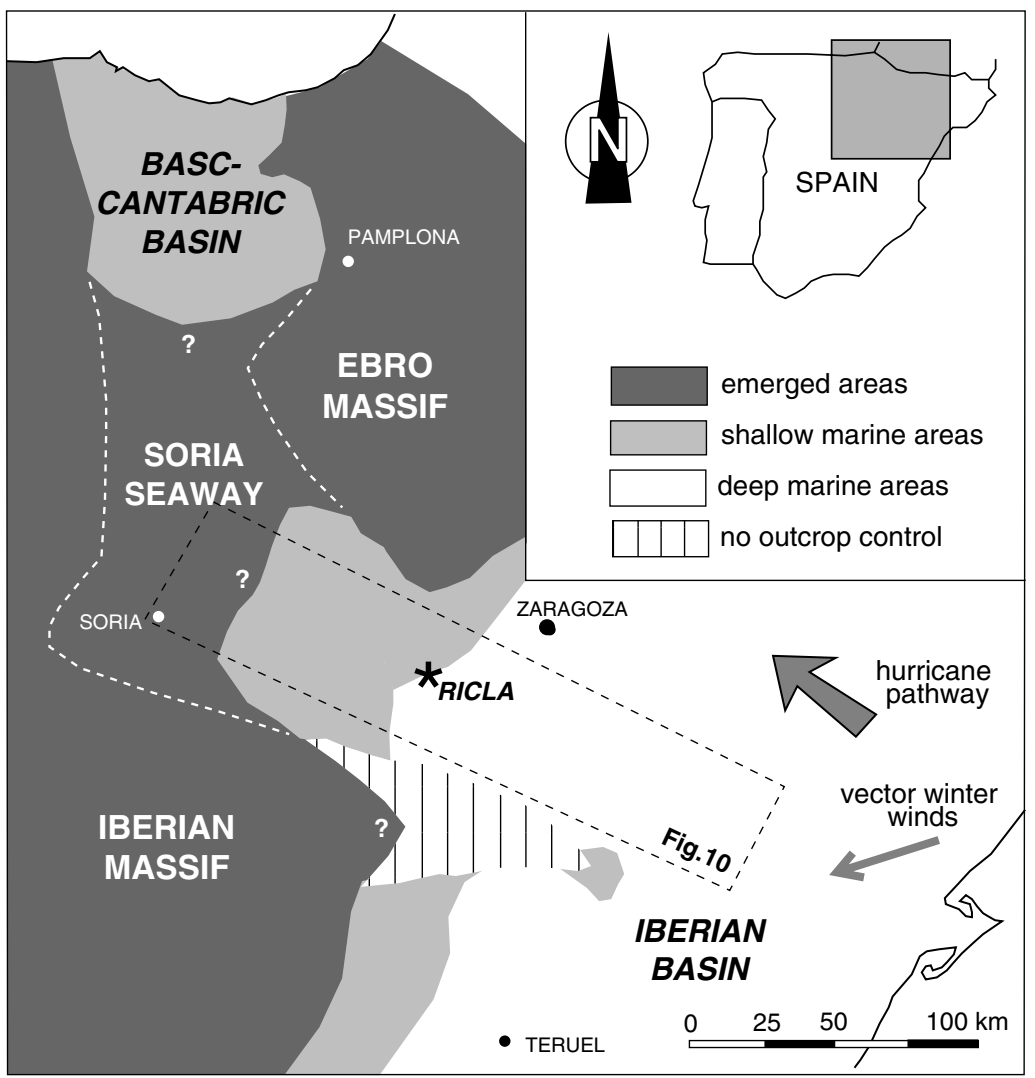

Fig. 1. Palaeogeography and main facies distribution in the northeastern Iberian Plate during middle-late Kimmeridgian. The Ricla outcrops records the transition from shallow to relatively deep environments.

\section{Stratigraphic setting}

The Kimmeridgian and the early Tithonian sedimentary rocks of the Iberian Basin are divided into two depositional sequences (Bádenas et al., 1998; Bádenas, 1999; Aurell et al., 2000). The age of the sequences and systems tracts and their correlation with the stratigraphic units in the Ricla outcrops is summarised in Fig. 2.

Sequence 1 spans from latest Oxfordian (Galar Subbzone) to the middle part of the late Kimmeridgian. It consists of a transgressive and a highstand systems tract. In the Ricla outcrops, the lower part of the TST is formed by marls and marly limestones (Sot de Chera Fm) that contain a rich assemblage of bivalves (Delvene et al., 1998). The marls are interpreted to have been deposited in the transition area between middle and outer-ramp environments.
Successive condensed calcareous levels with polyphase oncoids and ahermatypic corals, capped by encrusted and ferruginous surfaces, are recognised above these marls. On top of these condensed levels, the maximum flooding surface of Sequence 1 is located. The lower part of the HST of Sequence 1 corresponds to mid-outer ramp facies and consists of an alternation of sandy marls and skeletal sandy limestones with tempestites (lower part of Loriguilla Fm). This facies progressively grades up into the midand inner-ramp cross-bedded oolitic sandy grainstones (Ricla Mb). Above these facies, a cemented and ferruginous planar surface, with no evidence of subaerial exposure, is found. The facies gradation along with the absence of a subaerial exposure surface, indicate that the cross-bedded unit was developed during a relative stillstand of sea level, and therefore it corresponds to the upper part of the HST 


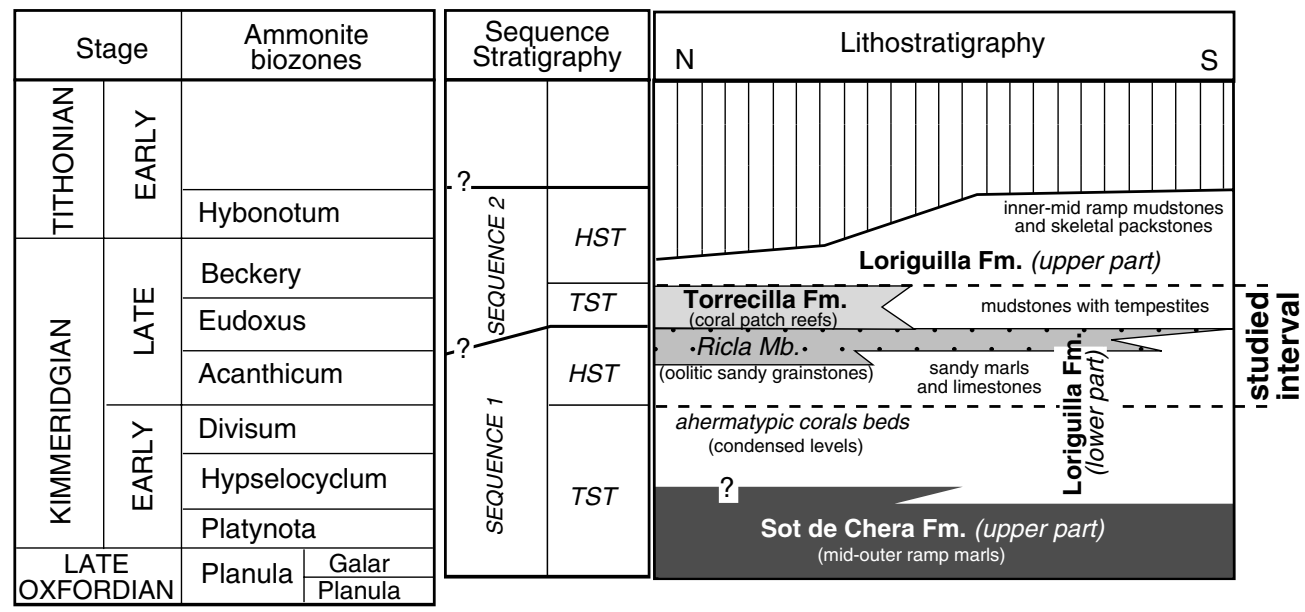

Fig. 2. Stratigraphic position of formations, systems tracts, Sequence 1 and 2, and their correlation to ammonite biozones in the Ricla outcrops. The studied interval corresponds to the HST-Sequence 1 and to the TST-Sequence 2.

of Sequence 1. The planar and cemented surface found on top of cross-bedded oolitic sandy grainstones corresponds to the upper boundary of the sequence.

Sequence 2 spans from the middle part of the late Kimmeridgian to the earliest Tithonian, and consists of a TST and HST. The lower boundary is related to a flooding event, indicated by a significant backstepping of facies and by evidence of sedimentary condensation in the lowermost facies of Sequence 2 (thin beds including reworked clasts and polyphase oncoids). The facies of the TST of Sequence 2 correspond to mid-ramp settings and comprise two end members. Shorewards the facies consist of coral patch reefs and associated facies (Torrecilla Fm), whereas more offshore areas are dominated by lime mudstones with different storm deposits (upper part of Loriguilla Fm). The facies of the HST of Sequence 2 consists of burrowed skeletal packstones and siltybioclastic mudstones and wackestones. They were deposited in restricted environments developed in the inner-ramp area.

\section{Facies analysis}

Facies analysis carried out in the outcrops of Ricla focuses on both the HST of Sequence 1 and the TST of Sequence 2. These two units give precise information on the relationship between the proximal and the distal realms of the Kimmeridgian carbonate ramp. These have been studied along eight logs, the location of which are shown in Fig. 3. The lateral and vertical facies distribution based on the correlation of these $\log$, along with the models of palaeoenvironmental reconstruction for each systems tract is shown in Fig. 4. Proximal facies are located to the north. Below we report on the brief description and the interpretation of sedimentary processes that gave rise to each facies. A more detailed facies description is offered in Tables 1 and 2 .

\subsection{Sequence 1-HST}

Six facies have been differentiated in the HST of Sequence 1 (Fig. 4). The facies A is recognised along the studied logs with no significant lateral facies and thickness variation (45-60 $\mathrm{m}$ thick). Above these facies, another set of facies (from facies B to facies F) progrades. Their maximum thickness is located to the north $(27 \mathrm{~m})$ and the facies pinch out southwards.

Facies A: siliciclastic mudstones and marls.

Facies A consists of two end members. The lower member is formed by an alternation of marls and burrowed marly limestones with scattered skeletal grains. The upper member consists of marly limestones-sandy marls and sandy skeletal limestones, arranged in metre-scale cycles. The proportion of marls in these cycles decreases upwards, whereas terrigenous grains increase. The components can be 


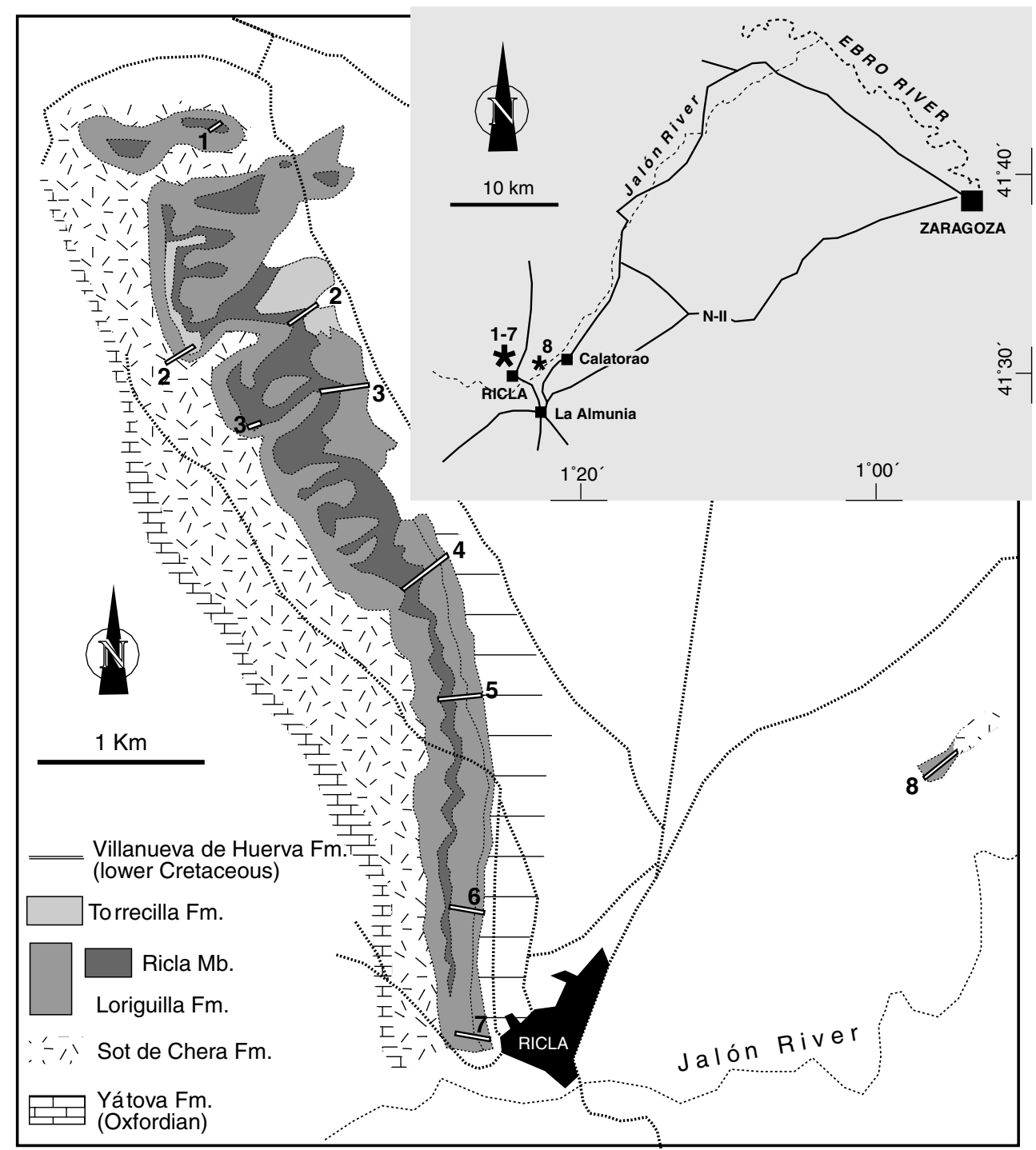

Fig. 3. Geographical location and distribution of lithostratigraphic units in the Ricla outcrops. The locations of the measured logs are also indicated.

found accumulated, forming centimetre-scale storm graded levels (tempestites). The facies has abundant burrows which in places, obliterate the storm layering.

Facies A reflects the progressive transition from low energy burrowed marly facies (outer ramp) to amalgamated and burrowed siliciclastic proximal tempestites deposited in mid-ramp environments.

Facies B: cross-bedded and channelled ooliticbioclastic sandstones.
Facies B is formed by coarsening and thickening upward cycles, up to $2.5 \mathrm{~m}$ thick. The lower part of the cycles consists of sandy limestones and sandstones. They have abundant burrows. Hummocky cross-stratification are occasionally found in the sandy levels. The upper part of the cycles is formed by sandstones and micro-conglomerates, which contain abundant skeletal grains and high-energy ooids. They show channel morphology and planar 
Table 1

Facies description (Sequence 1-HST)

\begin{tabular}{|c|c|c|c|}
\hline Facies & Lithology and stratiphication & Components & Sedimentary structures \\
\hline \multirow{2}{*}{ 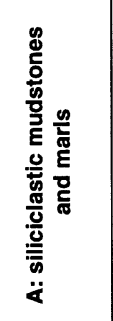 } & $\begin{array}{l}\text { Lower member: } \\
\text { Marls and marly limestones } \\
\text { (decimetre-scale beds) }\end{array}$ & $\begin{array}{l}\text { Scattered skeletal grains (bivalves, } \\
\text { brachiopods, serpulids and echinoids) }\end{array}$ & Bioturbation and abundant burrows (Chondrites) \\
\hline & $\begin{array}{l}\text { Upper member } \\
\text { Metre-scale cycles: } \\
\text { - Lower part: marly limestones and } \\
\text { sandy marls (upwards thickness } \\
\text { decrease); } \\
\text { - Upper part: sandy skeletal } \\
\text { limestones (beds up to } 0.5 \mathrm{~m} \text { thick) }\end{array}$ & $\begin{array}{l}\text { - } 20-40 \% \text { of terrigenous grains (coarse } \\
\text { quartz sand, micas and plant remains), } \\
\text { upwards increase; } \\
\text { - Scattered ooids, micritic clasts and bioclasts } \\
\text { (bivalves, serpulids, crinoids, echinoids, } \\
\text { brachiopods, and ahermatypic corals) }\end{array}$ & $\begin{array}{l}\text { - Centimetre-scale tempestites with planar } \\
\text { erosive lower boundary and parallel lamination. } \\
\text { Occasionally included in lime mudstones beds } \\
\text { up to } 0.2 \mathrm{~m} \text { thick; } \\
\text { - Bioturbation and abundants burrows } \\
\text { (Planolites, Chondrites) }\end{array}$ \\
\hline 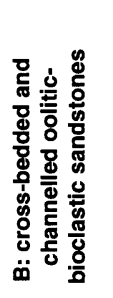 & $\begin{array}{l}\text { Thickening upward cycles } \\
\text { up to } 2.5 \mathrm{~m} \text { thick: } \\
\text { - Lower part: sandy limestones } \\
\text { and sandstones (beds up to } \\
0.3 \mathrm{~m} \text { thick) } \\
\text { - Upper part: sandstones and } \\
\text { microconglomerates (beds up } \\
\text { to } 1 \mathrm{~m} \text { thick) }\end{array}$ & $\begin{array}{l}\text { - Up to } 50 \% \text { of terrigenous grains (mainly } \\
\text { quartz sand, and also micas and plant } \\
\text { remains); } \\
\text { - Up to } 20 \% \text { of skeletal grains (echinoids, } \\
\text { bivalves, corals, brachiopods, gastropods, } \\
\text { benthic forams, bryozoans, Solenoporacean } \\
\text { algae and serpulids); } \\
\text { - Up to } 15 \% \text { of high energy ooids } \\
\text { (type } 3 \text { and } 4 \text { : Strasser, 1986) }\end{array}$ & $\begin{array}{l}\text { - Occasional oscilatory ripples, cross-lamination } \\
\text { and hummocky cross-stratification; } \\
\text { - Bioturbation and abundant burrows } \\
\text { (Thalassinoides, Planolites, Rhizocorallium) } \\
- \text { - Channels and planar cross-stratification } \\
\text { (sets up to } 0.4 \mathrm{~m} \text { thick, with mean dip-angle of } \\
\text { laminae of } 20^{\circ} \text { and S-SW migration); } \\
\text { - Bioturbation and abundant burrows in their tops }\end{array}$ \\
\hline 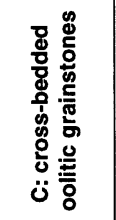 & $\begin{array}{l}\text { Oolitic sandy packstones and } \\
\text { grainstones arranged in beds } \\
0.2 \mathrm{~m} \text { to } 0.6 \mathrm{~m} \text { thick, with } \\
\text { intercalations of burrowed } \\
\text { marls (upwards decreasing) }\end{array}$ & $\begin{array}{l}\text { - } 30-50 \% \text { of high energy ooids (type } 3 \text { : } \\
\text { Strasser, } 1986 \text { ); } \\
\text { - } 5-20 \% \text { of medium and coarse quartz sand; } \\
\text { - Up to } 10 \% \text { of bioclasts (corals, echinoids, } \\
\text { bivalves, brachiopods and gastropods) }\end{array}$ & $\begin{array}{l}\text { - Lower part: parallel and cross-lamination; } \\
\text { - Upper part: issolated sets of planar cross- } \\
\text { stratification up to } 0.5 \mathrm{~m} \text { thick, with cross-strata } \\
\text { of similar thickness ( } \mathrm{S}-\mathrm{SW} \text { dominant migration) } \\
\text { and metre-scale wavelengtht hummocky } \\
\text { cross-stratification }\end{array}$ \\
\hline 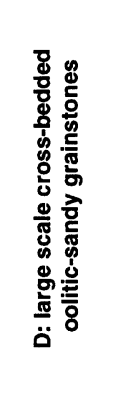 & $\begin{array}{l}\text { Oolitic sandy grainstones, with total } \\
\text { maximum thickness up to } 16.5 \mathrm{~m} \text {; } \\
\text { southwards are progressively thinner } \\
\text { Two sedimentary bodies formed by } \\
\text { a pile of sets of large-scale planar } \\
\text { cross-stratification }\end{array}$ & $\begin{array}{l}\text { - Up to } 50 \% \text { of high energy ooids (type } 3 \text { : } \\
\text { Strasser, } 1986 \text { ); } \\
\text { - Up to } 30 \% \text { of fine and medium } \\
\text { quartz sand; } \\
\text { - Scattered bioclasts (echinoids, gastropods, } \\
\text { bivalves, corals and forams) }\end{array}$ & $\begin{array}{l}\text { Sets of planar cross-stratification: average and } \\
\text { maximun thickness of } 1.5 \mathrm{~m} \text { and } 5 \mathrm{~m} \text {, respectively, } \\
\text { that decrease southwards; } \\
\text { Internal surfaces: } \\
\text { "S1 (boundaries of sets): planar erosive surfaces; } \\
\text { *S2 (boundaries of cross-strata) and L1 (internal } \\
\text { lamination: parallel to S2 ): both dipping to SW, } \\
\text { gentle slopes and asymptotic bases; } \\
\text { "S3 erosive and non erosive (boundaries of } \\
\text { couplets of cross-strata): similar orientation to } \\
\text { S2, but lower angles of inclination; } \\
\text { Local presence of metre-scale hummocky-swalley } \\
\text { waves and oscilatory ripples (straight crests } \\
\text { trending NE-SW) above S2 }\end{array}$ \\
\hline \multirow{2}{*}{ 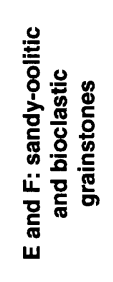 } & $\begin{array}{l}\text { E: Oolitic (locally skeletal) } \\
\text { grainstones (beds up to } 1 \mathrm{~m} \text { thick) }\end{array}$ & $\begin{array}{l}\text { - Up to } 40 \% \text { of high energy ooids (type } 3 \text { : } \\
\text { Strasser, } 1986 \text { ); } \\
\text { - Up to } 10 \% \text { of bioclasts (corals, echinoids, } \\
\text { bivalves, brachiopods, crinoids, bryozoans, } \\
\text { Solenoporacean algae, forams and gastropods) }\end{array}$ & $\begin{array}{l}\text { Planar cross-stratification (sets up to } 1 \mathrm{~m} \text { thick), } \\
\text { cross-strata of similar thickness with asymptotic } \\
\text { bases, upper bounding surfaces burrowed and } \\
\text { escrusted, dip-angle between } 20^{\circ}-25^{\circ} \text {, and } \mathrm{S} \\
\text { migration, from } 170^{\circ} \text { to } 190^{\circ}\end{array}$ \\
\hline & $\begin{array}{l}\text { F: Microconglomerates, oolitic- } \\
\text { bioclastic sandstones and } \\
\text { grainstones } \\
\text { (beds up to } 0.5 \mathrm{~m} \text { thick) }\end{array}$ & $\begin{array}{l}\text { - Up to } 30 \% \text { of medium quartz sand; } \\
\text { - Up to } 40 \% \text { of high energy ooids (type } 3 \text { : } \\
\text { Strasser, } 1986 \text { ); } \\
\text { - Up to } 20 \% \text { of skeletal grains (similar to facies E) }\end{array}$ & $\begin{array}{l}\text { - Cross-lamination; } \\
\text { - Planar cross-stratification (similar to facies E) } \\
\text { - Lime mudstones beds up to } 0.3 \text { m thick, eroded } \\
\text { by the overlying sandy and oolitic levels }\end{array}$ \\
\hline
\end{tabular}

cross-stratification, with dominant migration to the south-southwest.

The observed cycles were formed by the progradation of subtidal siliciclastic lobes and distributary chan- nels, similar to the rip channels described by Aigner (1985). As indicated by the palaeocurrent data, the migration of the lobes was due to unidirectional flows, induced probably by storms. Storm reworking 
in mid-ramp environments is also indicated by the presence of hummocky cross-stratification.

Facies $C$ : cross-bedded oolitic grainstones.

Facies $\mathrm{C}$ is formed by oolitic sandy packstones and grainstones. They include high-energy ooids and medium and coarse quartz sand. In the lower part of the facies, they display parallel and cross-lamination, and in the upper part, they show isolated sets of planar cross-stratification (dominant migration to the southsouthwest). Metre-scale wavelength hummocky cross-stratification is also recognised.

Facies $\mathrm{C}$ originated in mid-ramp settings by the migration of straight crested ripples and megaripples induced by unidirectional, storm-induced flows. The vertical trend observed in the bed forms, reflects the progressive increase in the energy of the environment.

Facies D: large-scale cross-bedded oolitic-sandy grainstones.

Facies $\mathrm{D}$ is formed by oolitic grainstones with variable amounts of quartz sand and high-energy ooids. The facies consist of two piled sedimentary bodies that have large-scale planar cross-bedding (Fig. 4). Northwards, the two bodies are amalgamated, with a total thickness of $16.5 \mathrm{~m}$. Southwards, the two bodies are well differentiated, and they become progressively thinner. The lateral extension of both bodies is more than $3 \mathrm{~km}$. The internal structure of each body is formed by a pile of sets, with maximum thickness of $5 \mathrm{~m}$, which are reduced to the south.

A number of internal surfaces can be differentiated in the individual sets (Fig. 5). S1 surfaces correspond to the bottom of the large-scale bedform (first-order bedding in Allen, 1980). S2 surfaces and the internal lamination (L1) indicate the successive growth stages of the bedforms. Both, L1 and S2 surfaces are dipping to the southwest (Fig. 6). This constant orientation indicates that the migration of the bedforms was due to unidirectional flows. Accretion was the dominant process in bedform migration, as indicated both by the gentle sloping of the S2 surfaces (Fig. 6), their asymptotic bases and the absence of coarser particles concentrated in wedges down the dip. Accretion processes have been related to high-velocity currents or storms (Halley and Evans, 1983; Scoffin, 1987).

S3 surfaces are boundaries of couplets of crossstrata. They have similar orientation to the S2 surfaces, but lower angles of inclination. They can be either erosive or non-erosive. S3 non-erosive surfaces (S3 in Fig. 5) were formed during bedform stabilisation and non-sedimentation episodes. S3 erosive surfaces (Fig. 5; S3e) were originated by the overtaking of the bedform by a faster-travelling form from behind, which is normally smaller than that overtaken (second-order bedding in Allen, 1980; see also Dalrymple, 1984; Berné et al., 1994).

According to the above exposed data, it is concluded that the observed structures were originated by the migration of dunes up to $5 \mathrm{~m}$ high, similar to the Class IIA Dunes of Allen (1980). Accretion of the dunes and the associated megaripples and ripples was due to high-energy unidirectional flows (storm-induced flows). The growth of the bedforms was episodic, alternating stages of non-sedimentation and even erosion.

On the other hand, the local presence of metre-scale hummocky-swaley waves and oscillatory ripples (crests trending northeast-southwest) above S2 surfaces, reveals the reworking of the sediment by oscillatory flows. The orientation of the ripples indicates a flow transverse to the one that induced the accretion of the dunes. They were probably originated by fair-weather waves, therefore indicating that the dunes occurred in the inner-ramp settings, as observed in the Holocene oolitic dunes (Ball, 1967; Hine, 1977; Harris, 1989).

Facies $E$ and F: sandy-oolitic and bioclastic grainstones.

Facies $\mathrm{E}$ is formed by oolitic grainstones that show planar cross-stratification. The sets have cross-strata dipping to the south. They have asymptotic bases and their upper bounding surfaces are frequently burrowed and encrusted. Facies $F$ represents the transition between the sandy bioclastic facies $\mathrm{B}$ and the dominant cross-bedded oolitic facies. As a result, facies $\mathrm{F}$ shows intermediate lithology and sedimentary structures. A particular feature is the presence of micritic beds up to $0.3 \mathrm{~m}$ thick, that can be generally eroded by the overlying sandy and oolitic levels.

Facies $\mathrm{E}$ and $\mathrm{F}$ correspond to mid-ramp deposits and are interpreted as having originated by the progradation of siliciclastic lobes and oolitic-sandy megaripples and ripples by unidirectional episodic flows. Bedform stabilisation indicated by the presence of burrows and crusts, and deposition of carbonate mud would take place during fair-weather episodes. 
Table 2

Facies description (Sequence 2, TST)

\begin{tabular}{|c|c|c|c|}
\hline Facies & Lithology and stratiphication & \multicolumn{2}{|c|}{ Components } \\
\hline 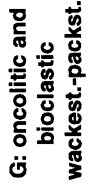 & $\begin{array}{l}\text { One or severall oncolitic beds, } \\
0.2 \mathrm{~m} \text { to } 0.4 \mathrm{~m} \text { thick } \\
\text { Local intercalation of burrowed } \\
\text { bioclastic marls and oncolitic } \\
\text { reworked levels (up to } 0.2 \mathrm{~m} \text { thick) }\end{array}$ & \multicolumn{2}{|c|}{$\begin{array}{l}\text { - } 30 \%-40 \% \text { of large (up to } 8 \mathrm{~cm} \text { ) ameboid polifasic oncoids (similar to type IV of Dahanayake, 1977) } \\
\text { "Nucleus: quartz grains, skeletal grains, (mainly corals), and micritic clasts; } \\
\text { "Coatings encustred by bryozooans, serpulids, Bacinella, Lithocodium and Girvanella, } \\
\text { and bored by bivalves; } \\
\text { - Up to } 25 \% \text { of skeletal grains (mainly corals and Solenoporacean algae; others: chaetetids, } \\
\text { benthic forams, bivalves, serpulids, echinoids and brachiopods); }\end{array}$} \\
\hline 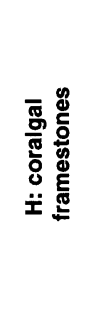 & $\begin{array}{l}\text { Metre-sized coralgal patch } \\
\text { reefs of framestone texture; } \\
\text { Associated skeletal and intraclastic } \\
\text { floatstones and rudstones (irregular } \\
\text { beds up to } 0.5 \mathrm{~m} \text { thick) }\end{array}$ & \multicolumn{2}{|c|}{$\begin{array}{l}\text { - } 30-40 \% \text { of corals, chaetetids, and in lower proportion Solenoporacean and Cyanophycean algae. } \\
\text { Centimetre to decimetre-size debris (bored by bivalves); } \\
\text { - Up to } 40 \% \text { of microbial crusts with micritic texture and abundant encrusters (sepulids, } \\
\text { Solenoporacean algae, bryozoans, Lithocodium, Bacinella and Koskinobullina). Bored by bivalves; } \\
-10-15 \% \text { of internal sediment of wackestone texture with bioclasts, debris of microbial crust, } \\
\text { ooids and quartz and carbonate silty grains } \\
-30 \%-50 \% \text { of skeletal grains (corals, chaetetids, echinoids, crinoids, bivalves, forams, gastropods, } \\
\text { Solenoporacean algae, bryozoans and serpulids); } \\
\text { - } 10-30 \% \text { of intraclasts (mainly clasts of microbial crusts); } \\
\text { - Scattered ooids and quartz sand }\end{array}$} \\
\hline 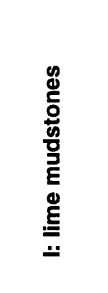 & $\begin{array}{l}\text { Well-bedded lime mudstones } \\
(0.2-0.7 \mathrm{~m} \text { thick) with } \\
\text { interbedded marly levels } \\
\text { (up to } 0.2 \mathrm{~m} \text { thick) }\end{array}$ & $\begin{array}{l}\text { Scattered terrigenous grains (quartz silt, } \\
\text { micas and plant remains) and skeletal grains } \\
\text { (bivalves, echinoids, serpulids, brachiopods, } \\
\text { forams and poorly preserved coccoliths) }\end{array}$ & $\begin{array}{l}\text { Sedimentary structures } \\
\text { - Milimetre to centimetre thick layers: } \\
\text { "composed of fine quartz sand, fragmented ooids } \\
\text { and bioclasts (bivalves, echinoids, gastropods, } \\
\text { corals, bryozoans and serpulids), } \\
\text { "with planar erosive bases, positive gradation to } \\
\text { low-angle cross lamination and, occasionally, } \\
\text { oscillatory ripples (straight crests with E-W trend) } \\
\text { - Abundants burrows (Chondrites, Rhizocorallium) }\end{array}$ \\
\hline 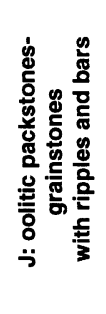 & $\begin{array}{l}\text { Oolitic (locally, sandy and } \\
\text { bioclastic) packstones- } \\
\text { grainstones, arranged in beds } \\
\text { of different morphology, mainly } \\
\text { ripples and bars }\end{array}$ & $\begin{array}{l}-20-50 \% \text { of fragmented and agregated high } \\
\text { energy ooids (type } 3 \text { and } 4 \text { : Strasser, } 1986) ; \\
\text { - Up to } 30 \% \text { of fine to medium quartz sand; } \\
\text { - Up to } 15 \% \text { of bioclasts (benthic forams, } \\
\text { Solenoporacean and Dasicladacean algae, } \\
\text { echinoids, crinoids, corals, bivalves, } \\
\text { brachiopods, bryozoans and gastropods) } \\
\text { - Scattered oncoids, intraclasts (mainly clasts } \\
\text { of microbial crusts) and plant remains }\end{array}$ & $\begin{array}{l}\text { - Levels with oscillatory ripples, with E-W trending } \\
\text { straight crests and maximun height and wavelength } \\
\text { of } 0.2 \mathrm{~m} \text { and } 1 \mathrm{~m} \text {; } \\
\text { - Bars with maximun thickness of } 1 \mathrm{~m} \text {. A single set } \\
\text { of planar cross-stratification, formed by sigmoidal } \\
\text { cross-strata up to } 0.5 \mathrm{~m} \text { thick: upper bounding } \\
\text { surfaces burrowed and escrusted, dip-angle of } \\
20^{\circ}-25^{\circ} \text {, and } \mathrm{S} \text { migration;local hummocky-swalley } \\
\text { wave morphology on top of the bars; } \\
\text { - Local beds up to } 0.5 \mathrm{~m} \text { thick with hummocky } \\
\text { cross-stratification }\end{array}$ \\
\hline 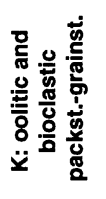 & $\begin{array}{l}\text { Oolitic and bioclastic } \\
\text { packstones-grainstones } \\
\text { (beds up to } 0.5 \mathrm{~m} \text { thick) }\end{array}$ & $\begin{array}{l}\text { - Up to } 50 \% \text { of bioclasts (mainly, benthic forams, } \\
\text { Solenoporacean algae, corals and chaetetids; } \\
\text { anothers: bivalves, brachiopods, echinoids, } \\
\text { gastropods, bryozoans and serpulids) } \\
\text { - Up to } 30 \% \text { of ooids (type } 3-4-5 \text { : Strasser, } 1986 \text { ) } \\
\text { - Up to } 20 \% \text { of terrigenous grains (fine and } \\
\text { medium quartz sand, micas and plant remains) }\end{array}$ & $\begin{array}{l}\text { - Abundant bioturbation, encustration (serpulids), } \\
\text { iron oxides and burrowing (Thalassinoides), and } \\
\text { locally, oscillatory ripples on top of the beds; } \\
\text { - Bars deposits similar to facies J, but with very } \\
\text { low inclination angles }\end{array}$ \\
\hline
\end{tabular}

\section{Palaeoenvironmental reconstruction.}

During the HST of Sequence 1, the progradation of inner-ramp sandy oolitic dunes over micritic and sandy mid-outer ramp deposits occurred (Fig. 4). Mid-ramp channels and storm lobes (facies B) were developed over the mid-outer ramp facies A. In the more proximal areas, oolitic mid-ramp deposits started to develop (facies C). These oolitic facies allowed the gradual nucleation and growth of two fields of oolitic dunes (facies D). The growth of the dunes involved the shallowing of the setting, that was eventually placed in inner-ramp environments. The offshore migration of the dunes was due to episodic storm-induced flows. The dunes were stabilised and 
affected by normal waves during fair-weather episodes. Mid-ramp deposits (oolitic megaripples and storm lobes: facies $\mathrm{E}$ and F), also originated by storm unidirectional flows, are found offshore to the dunes. We have not found any evidence to indicate the existence of tidal currents in the studied bedforms. This fact is coherent with the development of the dune fields in the interior area of an epeiric sea (see Tucker and Wright, 1990). Enclosed seas, or basins of small connections to open oceans tend to have very low tidal ranges (Walker, 1984).

The proportion of the different grains found in the distinguished facies is indicated in the upper part of Fig. 7. There is a progressive offshore decrease in the size and the relative proportion of the resedimented components: ooids and coarse detrital grains are dominant in the dunes and associated bedforms, whereas fine and medium quartz sand forms most of the offshore facies A. This fact indicates the progressive offshore decrease of the energy of the storm-induced flows. The progressive offshore reduction of the height of the bedforms also demonstrates the offshore decrease of the unidirectional flows.

\subsection{Sequence 2-TST}

The TST of Sequence 2 comprises five facies (from facies $\mathrm{G}$ to facies $\mathrm{K}$ in Fig. 4). They have an overall thickness of $45 \mathrm{~m}$, that decreases to the north (inshore).

Facies G: oncolitic and bioclastic wackestonespackstones.

Facies $\mathrm{G}$ is formed by one or several oncolitic levels, with total thickness ranging from 0.5 to $5 \mathrm{~m}$. Marly bioclastic and oncolitic reworked levels are locally interbedded between the oncolitic levels. These oncolitic levels contain large ameboid and polifasic oncoids. The coatings are encrusted by diverse organisms and are also boring bivalves. The more abundant skeletal grains of the facies are corals, solenoporacean algae and echinoderms.

The high-diversity association of micro-encrusters (Leinfelder et al., 1993) and the polifasic character of the oncoids reveals that they were formed in open marine environments (mid-ramp), under very low sedimentary rates, and with episodic hydrodynamic activity.
Facies $H$ : coralgal framestones.

Facies $\mathrm{H}$ includes both metre-sized coralgal patch reefs of framestone textures, and associated irregular levels of floatstones and rudstones. Facies $\mathrm{H}$ grades progressively offshore into well-bedded lime mudstones (facies I, Fig. 4).

The patch reefs are formed by variable proportions of debris of corals, chaetetids, solenoporacean algae and cyanophycean algae (Wnendt-Juber, 1990), microbial crusts (with micritic texture and abundant encrusters) and cavities with internal sediment. The skeletal debris and the microbial crusts are affected by boring bivalves. The floatstones and rudstones levels are dominated by debris of skeletal grains and intraclasts. Locally, they are associated with centimetre-scale bioclastic beds (tempestites) that include debris of corals and crinoids.

The growth of the patch reef took place in an open and shallow mid-ramp environment, as indicated by the high-diversity association of metazoans and micro-encrusters (Leinfelder et al., 1993; Aurell and Bádenas, 1997). Episodic flows induced by storms resulted in the partial destruction of the reefs. The bioclasts were incorporated into the inter-reef sediments (floatstone and rudstone levels, and oncolitic levels of facies $\mathrm{G}$ ).

Facies I: lime mudstones.

Facies I consists of well-bedded lime mudstones, with interbedded marly levels. The mudstones have abundant burrows and contain scattered skeletal and terrigenous grains. Poorly preserved coccoliths are occasionally found. The facies display abundant millimetre to centimetre thick layers composed of fine quartz sand, along with fragmented ooids and bioclasts. The layers show a succession of structures, including planar erosive bases and positive gradation. These structures are generally disrupted by burrowing (Fig. 8).

Facies I was deposited in a mid-ramp environment. A single micritic bed includes deposits formed during high- and low-energy episodes. The fine sand layers would correspond to distal tempestites (Aigner, 1985). The presence of oscillatory ripples on top of some of these layers indicates the reworking of the bottom sediment by storm waves. Sedimentation of carbonate mud and burrowing took place during fair-weather episodes. 


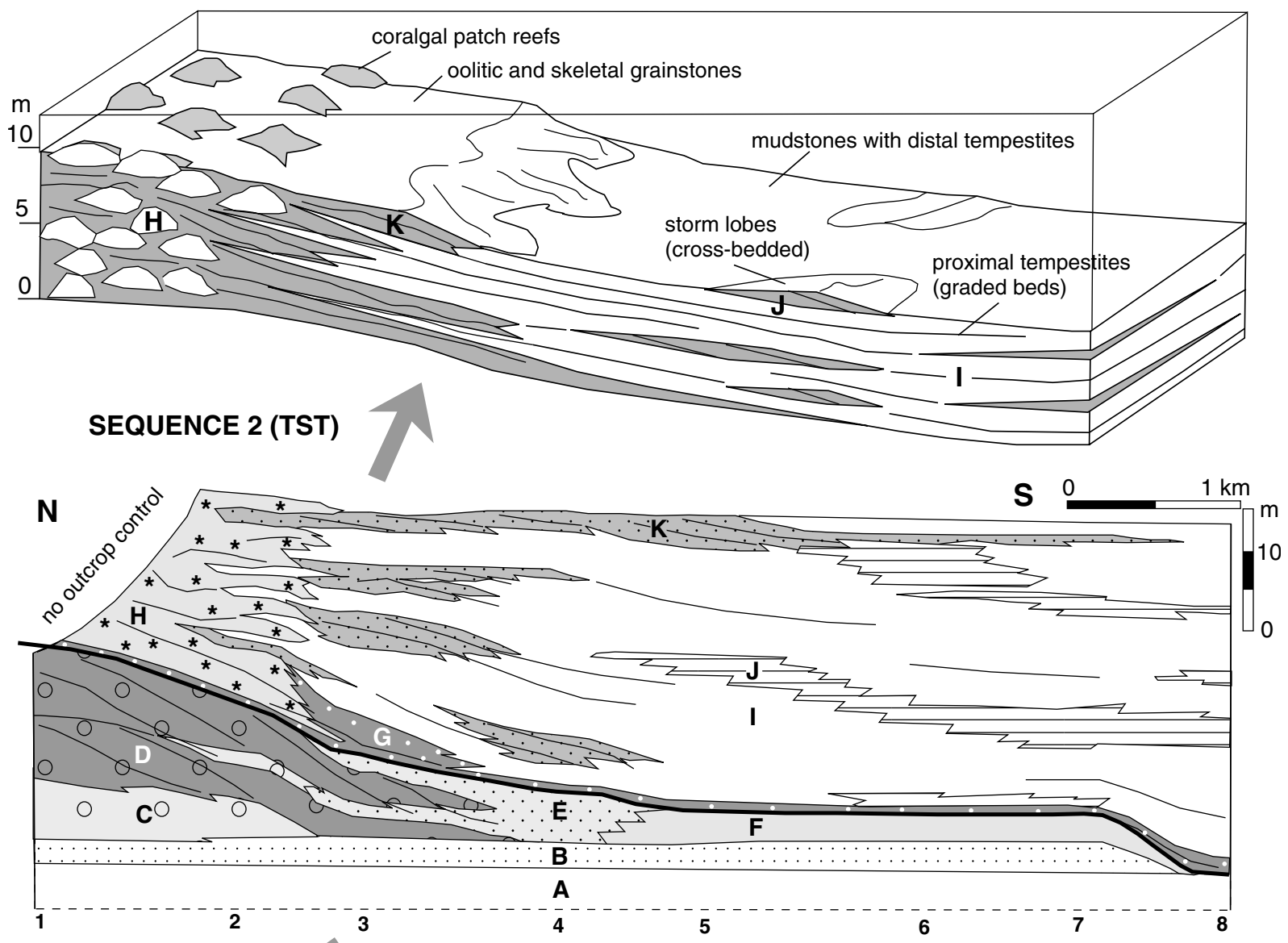

\section{SEQUENCE 1 (HST)}

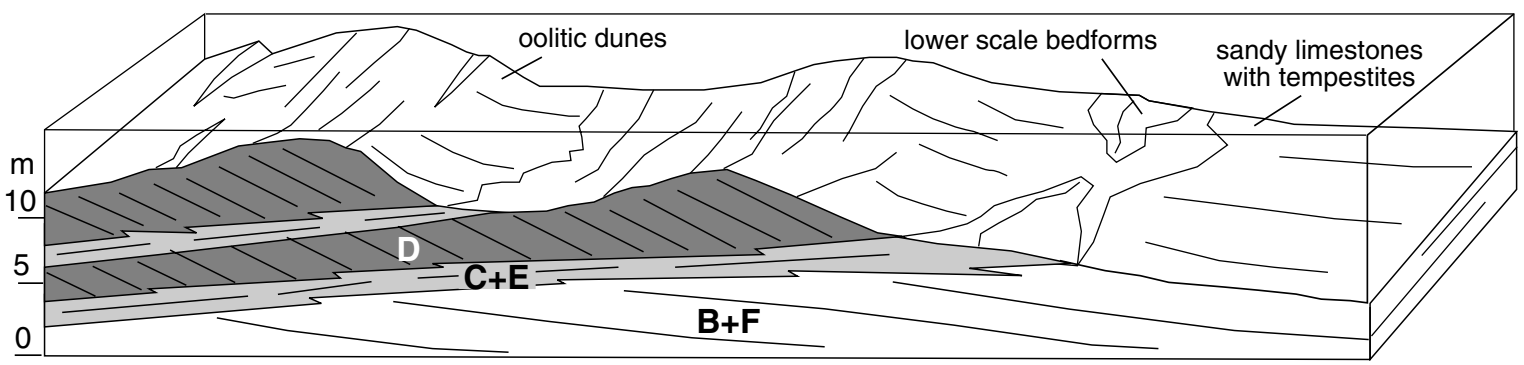

Fig. 4. The central part of the figure shows the facies distribution on the two studied systems tracts along the Ricla outcrops (numbers $1-8$ correspond to the measured logs; only the upper part of facies A has been represented). The paleoenvironmental reconstruction for each systems tract is also presented. 

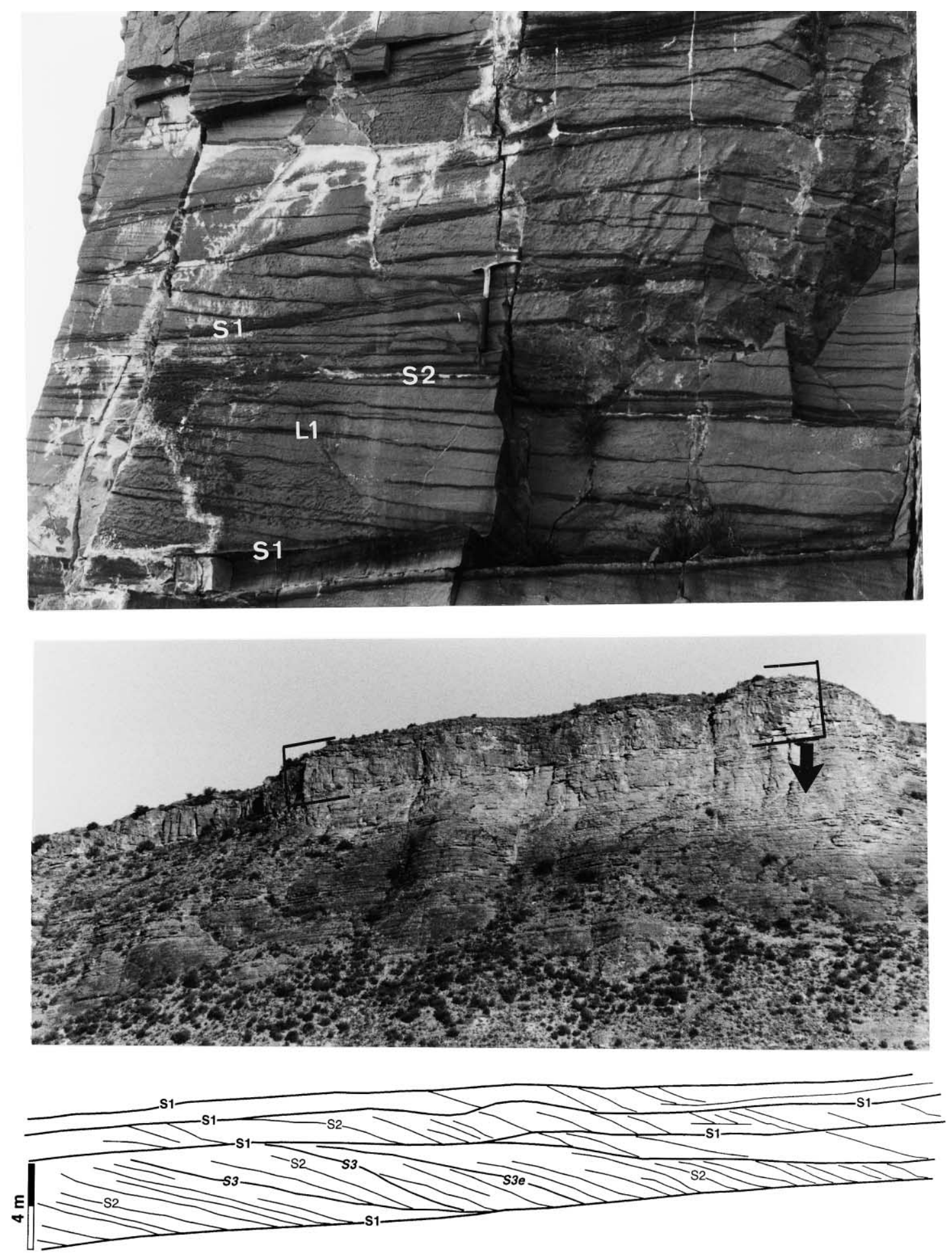

Fig. 5. Field examples showing the internal surfaces and lamination in Facies D. 
LOG $1(\mathrm{n}=30)$

DIP-ANGLE (S2)
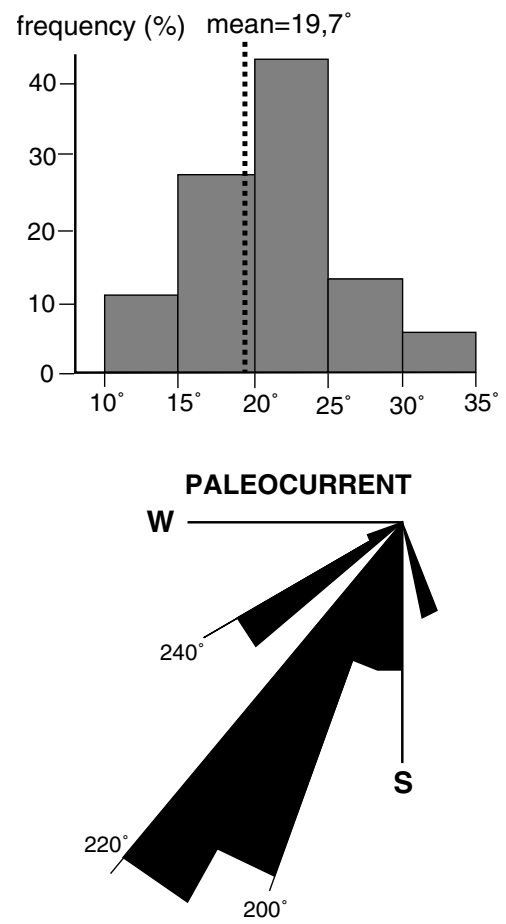

LOG $2(n=43)$

DIP-ANGLE (S2)
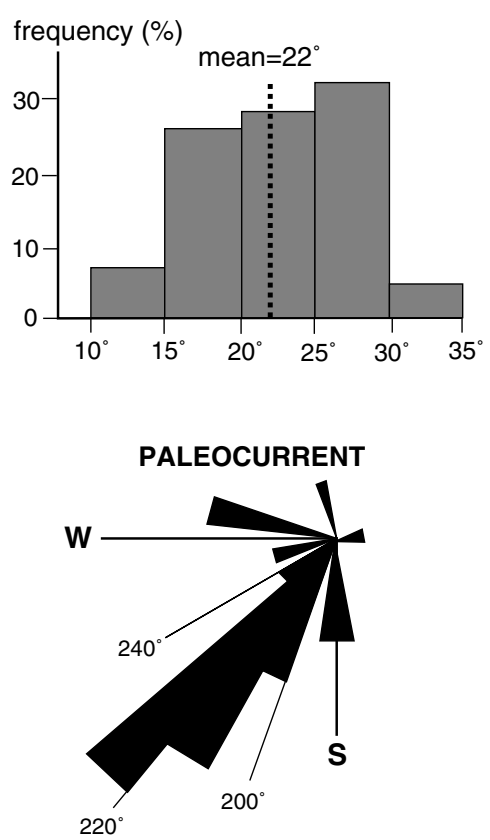

LOG $3(n=33)$

DIP-ANGLE (S2)

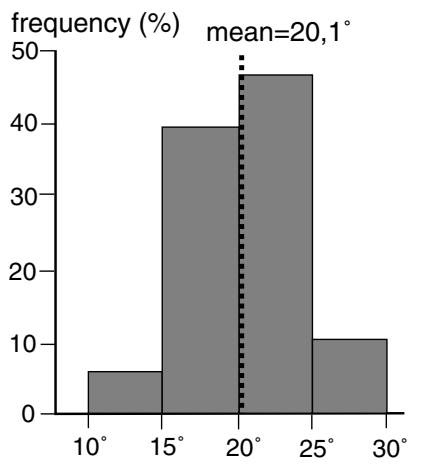

PALEOCURRENT

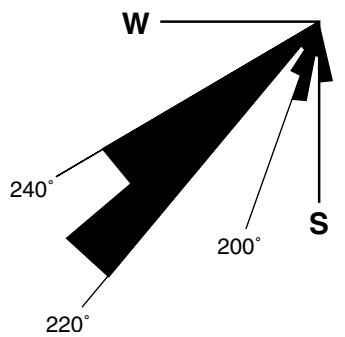

Fig. 6. Dip-angle and palaeocurrent data reconstructed from measurements on the S2 surfaces (facies D) along logs 1,2 and 3.

Facies J: oolitic packstone-grainstones with ripples and bars.

Facies $\mathbf{J}$ is formed by packstones and grainstones mainly composed of high-energy ooids, along with scarce bioclasts, including corals and fragments of microbial crusts. Two types of deposits are differentiated: oscillatory ripples and bars (Fig. 9). The ripples have east-west trending straight crests and are included in beds with up to $2 \mathrm{~km}$ of lateral extension. The bars are formed by a single set of planar-crossstratification with lateral extension up to $0.5 \mathrm{~km}$. The sets are formed by sigmoidal cross-strata dipping to the south. The upper bounding surfaces of the crossstrata are frequently burrowed and encrusted. The inclination angle of the cross-strata decreases laterally and there is a progressive increase in both the mud content and the burrow traces. Eventually, the bars become oscillatory ripples (Fig. 9).

Facies $\mathbf{J}$ was deposited in the mid-ramp area. The accretion of the bars was due to episodic storm- induced unidirectional flows. The lateral variation observed in the bars indicates the progressive offshore decrease of the current's velocity. The associated levels with ripples are interpreted as proximal tempestites reworked by storm waves (Aigner, 1985).

Facies K: oolitic and bioclastic packstone-grainstones.

Facies K consists of grain-supported textures, characterised by the high variety of skeletal grains and ooids. The facies is arranged in well-bedded levels up to $0.5 \mathrm{~m}$ thick, that show abundant bioturbation, iron oxides and burrowing on their tops. Bar deposits similar to those described for facies $\mathbf{J}$ are also recognised. According to the above exposed data, Facies K corresponds to storm bars and lobes accumulated in the mid-ramp setting under episodic unidirectional flows.

\section{Palaeoenvironmental reconstruction.}

The flooding of the ramp at the onset of the TST of Sequence 2 involved low sedimentation rates that 


\title{
SEQUENCE 1 (HST)
}

Facies D

DUNES
Facies C, E, F

LOWER SCALE BEDFORMS

$0.5 \mathrm{~m}$

$0.5 \mathrm{~m}$
Facies A

PROXIMAL

TEMPESTITES

cm's x 1-7 km
Facies A

OFFSHORE MUD

1-5 m

\begin{abstract}
cm's x 1-7 km
\end{abstract}

\section{ooids}

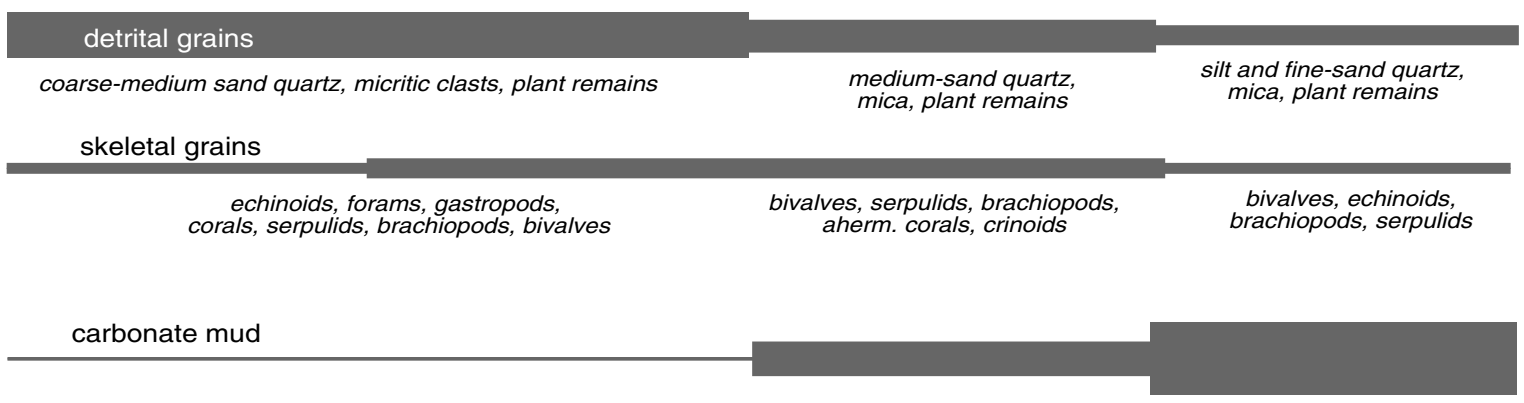

\section{SEQUENCE 2 (TST)}

\section{Facies $\mathbf{J}$ and $\mathbf{K}$ STORM LOBES AND BARS}

$1 \mathrm{~m} \times 0.1-0.5 \mathrm{~km}$

\section{Facies J \\ PROXIMAL TEMPESTITES}

cm's x 0.1-2 km

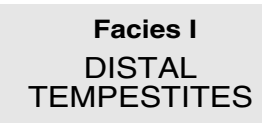

mm's x 1-7 km

\section{ooids}

\section{detrital grains}

coarse-medium sand quartz, plant remains

fine-sand quartz, plant remains

skeletal grains

echinoids, forams, gastropods,
$\begin{gathered}\text { corals, fragments of microbial } \\ \text { crusts, solenoporacean algae }\end{gathered}$
solenoporacean algae $\begin{gathered}\text { bivalves, echinoids, } \\ \text { gastropods }\end{gathered}$

Fig. 7. Relative proportions of grains found in the storm deposits present in Sequence 1 (HST) and in Sequence 2 (TST) in the Ricla outcrops. Average thickness and lateral extention of the different storm deposits are also indicated. 
resulted in the formation of oncolitic condensed levels (facies G) in the mid-ramp setting. However, inshore, in the proximal part of the mid-ramp, a set of coralgal patch reefs started to develop (facies $\mathrm{H}$ ). The lateral relationship between both facies is clearly demonstrated by the presence of coral debris in the cores of the oncoids of facies $\mathrm{G}$.

The growth of the reefs in the proximal mid-ramp setting was continuous across the whole TST of Sequence 2, giving rise to an agradational architecture (Fig. 4). The reefal facies laterally grades offshore into well-bedded lime mudstones which contain abundant distal tempestites (facies I) along with coarser storm deposits as proximal tempestites, bars and lobes (facies J and K). Storm-induced flows were the dominant process in the carbonate ramp. They involved both the partial destruction of the reefs and the offshore resedimentation of the produced debris. The accumulation of the coarser grains gave rise to the floatstones-rudstones levels associated with the reefs. Sandy and finer grains were transported further offshore forming different storm deposits. The studied outcrop allows us to verify the proximal-distal relationship between all these storm deposits. Storm lobes and bars (facies $\mathrm{K}$ ) tend to be concentrated near the reef dominated areas, whereas the bars and proximal tempestites (facies $\mathbf{J}$ ) are interbedded between lime mudstones further offshore.

The proportion of the different grains within the distinguished storm deposits along with their lateral and vertical extension is summarised in the lower part of Fig. 7. The ubiquitous presence of carbonate grains such as ooids, corals and fragments of microbial crusts, clearly shows that most of the grains originated in shallow-ramp areas. Moreover, there is a progressive offshore decrease in the size of the resedimented components: ooids are dominant in the storm lobes and bars, whereas fine quartz sand form most of the distal tempestites. The progressive changes in the proportion of the different grains reflect some sorting because of offshore transport, rather than variation of the source area. Maximum lateral transport from production sites to deposition of the sandy carbonate grains (i.e. ooids, skeletal grains) is at least $7 \mathrm{~km}$. The progressive offshore attenuation of the unidirectional storm flows is clearly shown by the progressive offshore thickness reduction of the storm-generated deposits, along with the increase of their lateral extent.
The lime mudstones associated with the storm deposits have scarce coccoliths, indicative of some pelagic contribution. However, the lateral relationship between the mudstones and both the reefal facies and the storm deposits, as well as the constant presence in the lime mudstones of detrital grains and resedimented skeletal grains, indicate that a significant part of the mud from this mid-ramp setting could have originated from shallower ramp areas as suspended load during storms.

\section{Models of facies distribution and processes on the ramp}

Facies analysis carried out in the Ricla outcrops allows us a first approach to the dominant sedimentary processes and to the existing relationship between the shallow and deep-ramp environments. A more general view of the factors that controlled the sedimentation in the carbonate ramp can be obtained by comparing the Ricla outcrops to those located in more proximal and distal basin domains. General facies distribution of the carbonate ramp in the north Iberian Basin along from the two considered stages is shown in Fig. 10. Additional data to construct these maps was taken from previous works (Benke et al., 1981; Alonso and Mas, 1990; Meléndez et al., 1990; Aurell et al., 1997; Bádenas et al., 1998; Pérez-Urresti et al., 1998).

Each stage of evolution represents a different context in the ramp development, giving rise to two models of facies distribution and processes. Model 1 corresponds to the development of a mixed carbonatesiliciclastic ramp during relative sea level highstand, whereas Model 2 represents a pure carbonate ramp developed during a relative sea level rise. Below we describe the overall distribution of facies and processes of the carbonate ramp in the northern part of the Iberian Basin in the two models. We also discuss about the factors controlling facies patterns and the application and consequences of the two facies distribution models.

\subsection{Description of the models}

Model 1: development of a mixed carbonate-siliciclastic ramp during relative sea level highstand (HSTSequence 1).

During the HST of Sequence 1, inner ramp and 

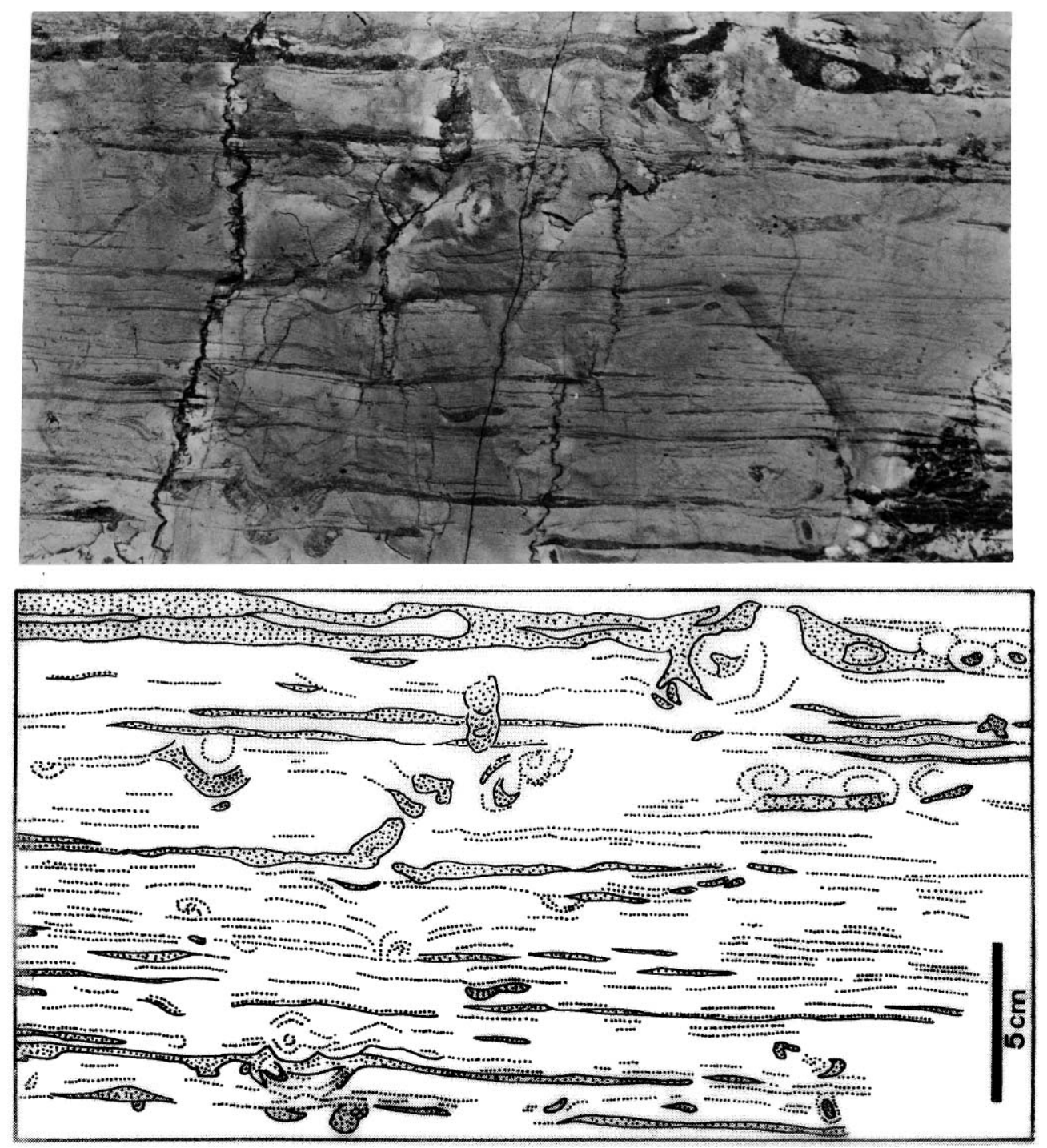

Fig. 8. Field aspect of the distal tempestites present in facies I.

proximal mid-ramp domains were covered by coralgal reefs (interior areas of the northwest Iberian basin: Fig. 10) and sandy oolitic dunes (Ricla area). These facies prograded over siliciclastic mudstones and marls with abundant amalgamated proximal tempestites. This facies was arranged in a northeast-southwest trending belt, developed in the distal part of the mid-ramp. Offshore, the outer-ramp facies is represented by a rhythmic alternation of mudstones and marls arranged in beds $0.2-0.5 \mathrm{~m}$ thick. They show abundant terrigenous grains (quartz silt size, mica, plant remains, argillaceous minerals) in the more proximal domains, which reduce progressively offshore. The facies also contains scarce and badly preserved fossils (bivalves, crinoids, serpulids, benthic forams, ammonites) and abundant Chondrites burrows. In the more distal domains, marls and interbedded limestones with abundant ammonites are recognised. In general, there is a progressive offshore decrease of the overall thickness of this systems tract, 

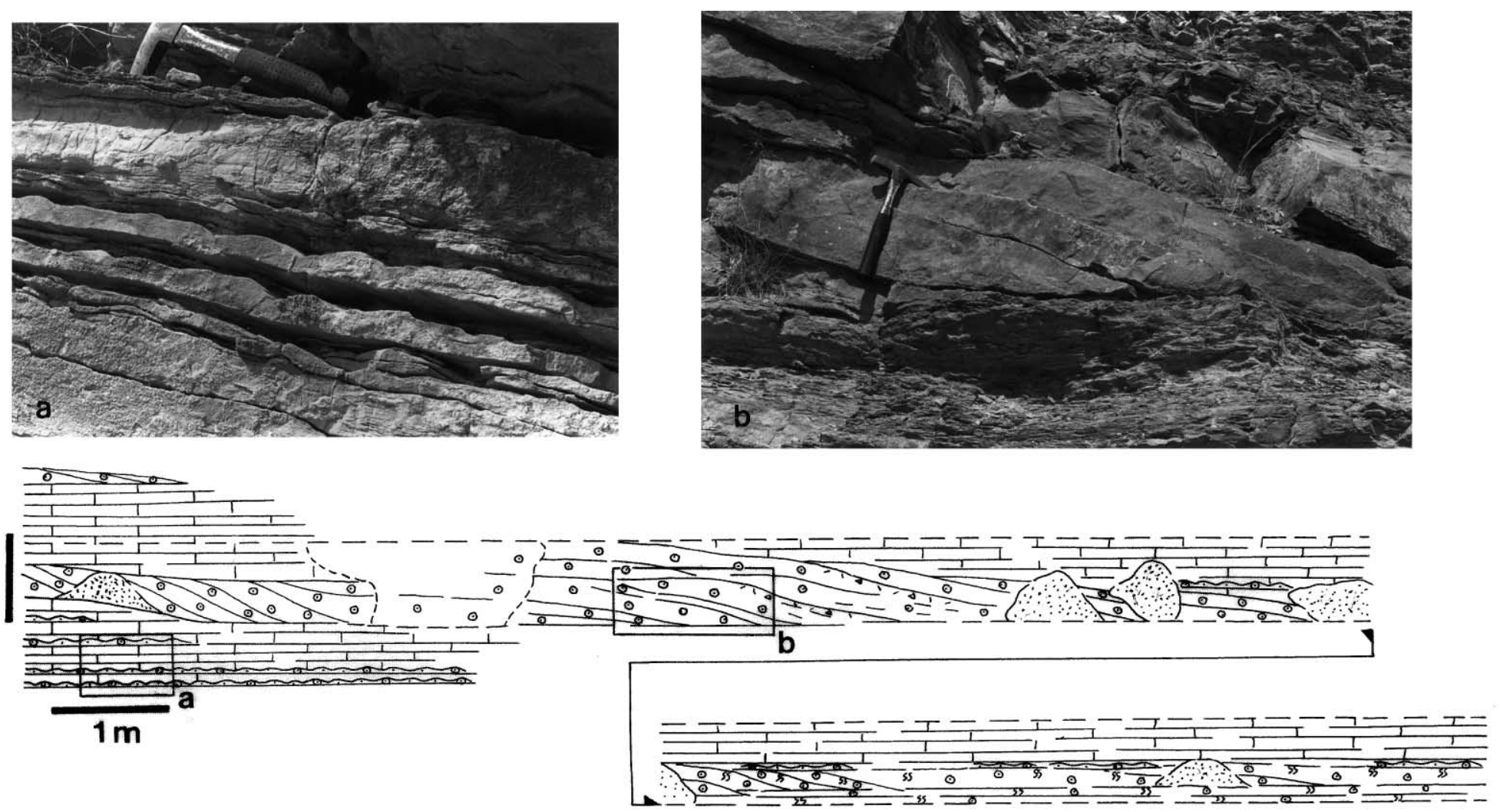

Fig. 9. Oscillatory ripples and planar-cross bedding present in facies J. The lower outcrop sketch shows the lateral transition between these two kinds of deposits. The location of the photos is also indicated. 
from the $80 \mathrm{~m}$ measured in Ricla to less than $15 \mathrm{~m}$ in the more distal localities (Meléndez et al., 1990; Bádenas, 1999).

The overall distribution of the facies belts indicates that the ramp was open to the southeast. However, a local step to the south in the Ricla area was found, as shown by the local facies distribution. The measured paleocurrents in the sandy oolitic dunes of Ricla (directed to the south-southwest) would be parallel to this local step (Fig. 10). This fact reflects a preferred sediment transport direction according to the local inclination of the ramp and moreover indicates that the source area for the siliciclastic supply was located to the north (Ebro Massif).

The shallow areas of the Iberian basin were affected by winter storms and hurricanes that had a northwest pathway (see Fig. 1; Marsaglia and Klein, 1983). The major storms, particularly hurricanes, would create high water elevations (storm surges) that would eventually result in a bottom return flow (storm surge ebb or return current) capable of transporting sand directly seaward, rather than parallel to isobaths (Walker, 1984). According to the pathway of the winter storms and hurricanes and the distribution of the emerged areas, the offshore migration of the dunes was due to these episodic return currents. The progressive southward (seaward) reduction of the dunes, indicates the coeval offshore decrease of the energy of the return currents (Rubin and McCulloch, 1979).

The return currents eventually generated density (turbidity) currents that involved the offshore resedimentation of both the siliciclastic grains supplied from emergent areas, and the carbonate grains produced in shallow areas. The pathway of the turbidity currents would be driven downslope by gravity, following the general inclination of the ramp, and therefore they would be deflected to the southeast, south of the Ricla area (see white arrow in Fig. 10). The progressive offshore attenuation of the turbidity currents controls the facies distribution in the midouter ramp domains. In the distal mid-ramp, the coarser resedimented grains are concentrated in the successive storm beds (tempestites). Only finer grains (silt and fine sand) reached the outer-ramp areas. Moreover, a variable amount of the mud accumulated in the outer-ramp environments could also have originated from shallow-water domains by the offshore directed, storm-generated turbidity currents.
Model 2: development of a carbonate ramp during a relative sea level rise (TST-Sequence 2).

During the TST of Sequence 2, inner-ramp and proximal mid-ramp environment were the site of coralgal reef growth (Fig. 10). In the distal part of the mid-ramp, the deposition of carbonate mud along with different coarse-grained storm beds took place. Further offshore, in the outer ramp, a rhythmic alternation of well-bedded lime mudstones and marls is found. Mudstone facies have a very low proportion of detrital grains (quartz silt, mica) and scattered generally well-preserved fossils (brachiopods, bivalves, serpulids, forams, ahermatypic corals, ammonites, coccoliths). The Chondrites burrows are abundant. In the more distal domains of the outer ramp, the facies contain more abundant ammonites and siliceous sponges (Geyer and Pelleduhn, 1981). In general, the overall thickness of this systems tract is constant along the basin and ranges from 30 to $40 \mathrm{~m}$.

Facies analysis carried out on the Ricla outcrops indicates the importance of the storm-induced flows controlling the sedimentation in the carbonate ramp. As in the previously described Model 1, hurricanes and winter storms would generate return currents. They involved the accretion of the bars and storm lobes developed in the distal part of the mid-ramp. The coarse grains found on these storm beds originated in shallow areas. The return currents evolved offshore into turbidity currents that brought part of the sediment produced in shallow areas to the outerramp domains, following the general slope of the ramp (to the southeast, see white arrow in Fig. 10). Coarse and fine-grained tempestites originating from these turbidity currents are concentrated in the proximal part of the mid-ramp. As in Model 1, from the exposed data, we also suggest that a significant part of the mud could have originated from the areas dominated by coral reefs, and it would be resedimented offshore by density currents.

\subsection{Discussion of the models}

The facies distribution models presented in our work have offered the possibility to document the lateral and vertical facies transition between the relatively shallow to deep domains of the carbonate ramp developed during the Kimmeridgian in the northern part of the Iberian basin. From our data, we 

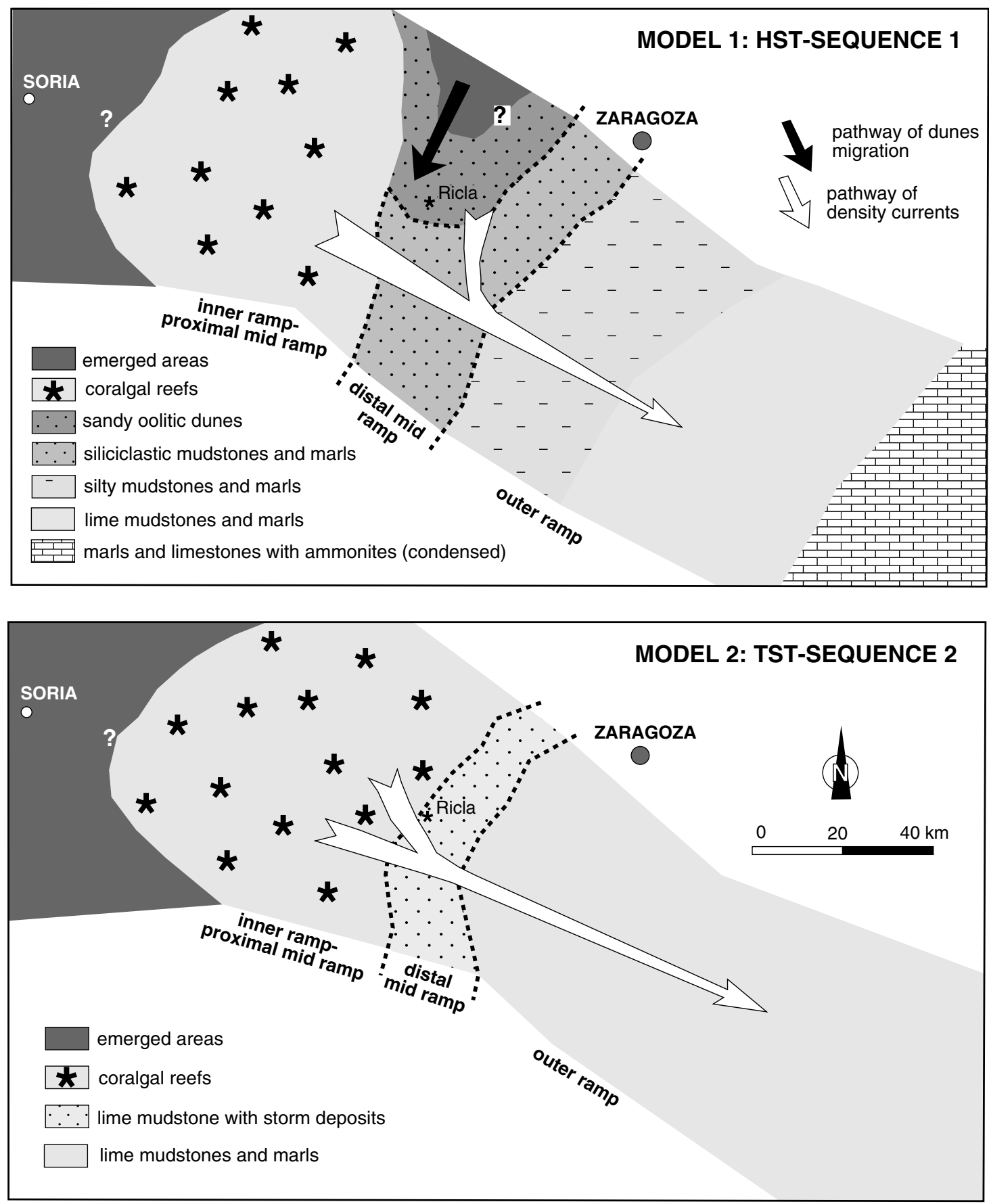

Fig. 10. Overall facies distribution in the carbonate ramps developed in the northern Iberian basin during the middle part of the Kimmeridgian (Model 1) and during the upper Kimmeridgian (Model 2). 
conclude that there was a close genetic relationship between the shallow areas of the carbonate ramp, and the relatively deep domains.

In the two models, we have suggested that a significant part of the carbonate mud accumulated in mid- and outer-ramp settings could have originated from shallow-water domains by the offshore directed, stormgenerated turbidity currents. In addition, the offshore carbonate mud shows a very small proportion of calcareous nannoplankton (i.e. coccoliths). It is therefore likely that they have a number of origins, including pelagic sedimentation and in-shore derived mud (Aurell et al., 1995, 1998). In the Iberian carbonate-ramp, the pelagic contribution to the origin of this mud remains uncertain.

The resedimented origin of the carbonate mud accumulated in the outer ramp has been proposed in several works. Elrick et al. (1991) have interpreted a carbonate outer ramp-slope deposits to have resulted from periods of intensified storm activity alternating with periods of little or no storm activity. During times of intensified storm activity, there is an increase on the amount of the shallow-ramp carbonate sediment transported offshore. The micrite derived from shallow carbonate platforms, along with the pelagic supply, has been also considered by Dromart (1989) to explain the origin of the fine-grained carbonates deposited in an outer-ramp setting.

In the two proposed models, the resedimented origin is in agreement with the composition of the mud accumulated in the outer-ramp settings, which clearly reflects the facies variation in the interior areas of the ramp during the two stages of evolution considered. During the Model 1, there is a good correlation between the ubiquitous presence of quartz sand in some interior areas of the ramp (i.e. sandy oolitic dunes) and the larger terrigenous content in the mud accumulated in the outer-ramp settings. The more pure carbonate inner-ramp facies observed in Model 2 is also in agreement to the predominant carbonate composition of the offshore mud.

The overall basinward decrease in thickness of the muddy facies during the stage of stillstand of sea level (Model 1) is coherent with inshore origin. In contrast, domination by pelagic sedimentation would be expected to result in a more homogeneous thickness distribution or a more even offshore thickening (Aurell et al., 1998). However, the overall thickness of the carbonate mud accumulated offshore is larger in
Model 2 than in Model 1. This fact can be interpreted in two ways: either there is an increase of the pelagic contribution from Model 1 to Model 2 and/or there is an increase of the shallow production in the reef dominated areas and, consequently, larger inshore contribution in the offshore mud during the stage of sea level rise (Model 2).

The changes in the pelagic contribution has been related by some authors to climatic changes. The pelagic contribution is larger during cool climate than during warm/humid climate (Gawenda et al., 1999). However, according to the available palaeoclimatic reconstructions, there was no significant climatic change during the late Kimmeridgian-Tithonian transition (Weissert and Mohr, 1996). In contrast, the carbonate production in the shallow areas of the ramp would be favoured during the time of sea level rise (i.e. Model 2), providing space for the growth of coralgal reef. They were able to keep-up with the rising sea level, as demonstrated by the observed aggradational geometries in the Ricla outcrops (Fig. 4). In addition, the growth potential of coral reefs was favoured by the low terrigenous supply during this stage of evolution of the ramp. Consequently, the inshore contribution of the mud accumulated in outer-ramp areas was larger during the times of sea level rise (Model 2).

These observations have some consequences in the analysis and correlation between the shallow and relatively deep areas of the basin. In contrast to other proposed models (see discussion in Pasquier and Strasser, 1997 and Betzler et al., 1999), we have observed that the thicker carbonate successions in the outer-ramp setting would correlate to periods of relative sea level rise, when the shallow areas of the ramp were entirely flooded and the vertical aggradation of the reefs took place. During times of sea level stabilisation, larger terrigenous supply combined with the progressive reduction of the accommodation in the shallow areas results in relatively lower carbonate production, that would explain the observed sedimentary condensation in the outer-ramp areas.

\section{Conclusions}

Two general models showing the facies distribution 
and the processes that controlled the sedimentation in the Kimmeridgian carbonate ramp have been established. The first conclusion that can be reached from the observation of the two models concerns the importance of the transition area from shallow to relatively deep-ramp domains, as a key point to better understanding the sedimentary dynamics of the ramp. In the studied case, it would be very difficult to establish the relationship between the shallow and deep domains of the Kimmeridgian ramp and to get precise information of its sedimentary processes in the absence of the studied Ricla outcrops. Due to the low inclination and the large lateral extension of the carbonate ramps, the correlation between shallow and relatively deep areas is usually based on the correlation of separated stratigraphic sections, rather than direct outcrop reconstruction. Accordingly, we believe that the two models presented can be used as predictive facies distribution models in the analysis of ancient carbonate ramps.

The two models of sedimentary processes and facies distribution obtained in our work, were developed in different sedimentary context: Model 1 corresponds to a mixed carbonate-siliciclastic ramp, that grew during low rise and stillstand of sea level (Sequence 1-HST), whereas Model 2 is a pure carbonate ramp, developed during a rapid rise of sea level (Sequence 2-TST). However, there is a common sedimentary factor in both instances: the storm-induced flows that played a fundamental role in the observed resultant facies and in their vertical and lateral distribution. Summing up, three factors control the geometry and facies distribution across the ramp:

1. Carbonate productivity, that shows higher production rates in the shallow-ramp domains (coral reef and sandy oolitic dunes in Model 1 and reefs in Model 2) than in deeper domains, where there is no indication of significant pelagic or benthic production.

2. The activity of unidirectional return flows induced by winter storms and hurricanes. The data reported in our work allows the definition of the pathway followed by the storm-induced flows, as well as the important role played in the redistribution of the sediment (carbonates and terrigenous grains) across the ramp. A significant bulk of the carbonate mud produced in shallow areas would be eventually resedimented in the outer ramp as a suspended load in the density currents induced by winter storms and hurricanes.

3. Relative sea level variation. Slow relative sea level rise and stillstand in Model 1 involved a rapid progradation of the inner and proximal mid-ramp facies and a locally important siliciclastic supply. The rapid relative sea level rise of Model 2 is determinant in the dominance of the carbonate facies or the correlative decrease of the siliciclastic supply because of the flooding of the emergent areas. On the other hand, the elevated production in the shallow areas dominated by reefs was able to compensate for the created accommodation, as is shown by the presence of an aggradational geometry in the transition area between shallow and deep-ramp domains.

The presence of relatively thick sections of sediments in the outer-ramp settings during times of sea level rise (instead of the condensed sections observed during the highstand of sea level), can be explained by the increase of the shallow production in reef dominated areas. The larger accommodation during sea level rise in shallow areas, combined with the presence of clear waters with no significant terrigenous supply, would be determinant in the reef growth. Therefore, it is possible that the inshore contribution on the mud accumulated in outer-ramp areas was larger in Model 2 than in Model 1.

\section{Acknowledgements}

The authors are indebted to Amy Boylan, Francesc Calvet and Javier Martín-Chivelet for critical reading and improving suggestions of the early version of the manuscript. This paper is a contribution to the research projects of the Government of Aragón (D.G.A.) P35/97 and to the DGICYT project PB951142.

\section{References}

Aigner, T., 1985. Storm depositional systems. Dynamic stratigraphy in modern and ancient shallow-marine sequences. Lecture notes in Earth Sciences, 3. Springer, Berlin (174pp.).

Allen, J.R.L., 1980. Sand waves: a model of origin and sedimentary structures. Sediment. Geol. 26, 281-328. 
Alonso, A., Mas, J.R., 1990. El Jurásico superior en el sector Demanda-Cameros (La Rioja-Soria). Cuad. Geol. Ibérica 14, 173-198.

Aurell, M., Bádenas, B., 1997. The pinnacle reefs of Jabaloyas (Late Kimmeridgian, NE Spain): vertical zonation and associated facies related to sea level changes. Cuad. Geol. Ibérica 22, 37-64.

Aurell, M., Meléndez, A., 1993. Sedimentary evolution and sequence stratigraphy of the Upper Jurassic in the central Iberian Chain, northeast Spain. In: Possamentier, H.W. et al. (Eds.). Sequence Stratigraphy and Facies Associations. Int. Assoc. Sediment., Spec. Publ. 18, pp. 343-368.

Aurell, M., Bosence, D., Waltham, D., 1995. Carbonate ramp depositional systems from a late Jurassic epeiric platform (Iberian basin, Spain): a combined computer modelling and outcrop analysis. Sedimentology 42, 75-94.

Aurell, M., Bádenas, B., Bello, J., Delvene, G., Meléndez, G., Pérez-Urresti, I., Ramajo, J., 1997. El Jurásico superior de Calanda-Mas de las Matas. Libro Guía de Excursiones, IV Congreso Jurásico de España, Public. Sem. Paleont., Univ. Zaragoza, vol. 2, pp. 119-144.

Aurell, M., Bádenas, B., Bosence, D., Waltham, D., 1998. Carbonate production and offshore transport on a Late Jurassic carbonate ramp (Kimmeridgian, Iberian basin, NE Spain): evidence from outcrops and copmuter modelling. Geol. Soc. Lond., Spec. Publ. 149, 137-161.

Aurell, M., Meléndez, G., Bádenas, B., Pérez-Urrest, Ramajo, J., 2000. Sequence Stratigraphy of the Callovian-Berriasian (Middle Jurassic-Lower Creataceous) of the Iberian basin (NE Spain). Advances in Jurassic Research 2000, Hall, R.L., Smith, P.L. (Eds.). Geo Res. Forum 6, 281-292.

Ball, M.M., 1967. Carbonate Sand Bodies of Florida and the Bahamas. J. Sediment. Petrol. 37, 556-591.

Bádenas, B., 1999. La sedimentación en las rampas carbonatadas del Kimmeridigense en las cuencas del Este de la Placa Ibérica. $\mathrm{PhD}$ thesis, University of Zaragoza, 256pp.

Bádenas, B., Aurell, M., Pérez-Urresti, I., Delvene, G., 1998. Estratigrafía y Evolución sedimentaria del Oxfordiense superiorTitónico inferior en Ricla (Zaragoza). Geogaceta 24, 35-38.

Benke, K., Dürkoop, A., Errenst, C., Mensink, H., 1981. Die korallenkalke im Ober-Jura der nord-westlichen Iberischen Ketten (Spanien). Facies 4, 27-94.

Berné, S., Trentesaux, A., Stolk, A., Missiaen, T., Batist, M., 1994. Architecture and long term evolution of a tidal sandbank: the Middelkerke bank (southern North Sea). Mar. Geol. 121, 57-72.

Betzler, C., Reijmer, J., Bernet, K., Eberly, G., Anselmetti, F., 1999. Sedimentary patterns and geometries of the Bahamian outer carbonate ramp (Miocene-Lower Pliocene, Great Bahama Bank). Sedimentology 46, 1127-1143.

Bosence, D.W.J., Pomar, L., Waltham, D.A., Lankester, T.G., 1994. Computer modelling of a Miocene carbonate platform, Spain. Am. Assoc. Pet. Geol. Bull. 78, 247-266.

Burchette, T.P., Wright, V.P., 1992. Carbonate ramp depositional systems. Sediment. Geol. 79, 3-57.

Burchette, T.P., Wright, V.P., Faulkner, T.J., 1990. Oolitic sandbody depositional models and geometries, Mississippian of southwest Britain: implications for petroleum exploration in carbonate ramp settings. Sediment. Geol. 68, 87-115.

Dalrymple, R.W., 1984. Morphology and internal structure of sandwaves in the Bay of Fundy. Sedimentology 31, 365-382.

Delvene, G., Ramajo, J., Pérez-Urresti, I., 1998. Nuevos datos sobre Paleontología y Bioestratigrafía en la formación Sot de Chera (Jurásico superior) de Ricla, Zaragoza. Coloquios Paleontol. 49, 77-95.

Dromart, G., 1989. Deposition of Upper Jurassic fine-grained limestones in the western Subalpine Basin, France. Palaeogeogr., Palaeoclimatol., Palaeoecol. 69, 23-43.

Elrick, M., Read, J.F., Coruh, C., 1991. Short-term paleoclimatic fluctuations expressed in lower Mississippian ramp-slope deposits, southwestern Montana. Geology 19, 799-802.

Gawenda, P., Winkler, W., Schmitz, B., Adatte, T., 1999. Climate and bioproductivity control on carbonate turbidite sedimentation (Paleocene to Earliest Eocene, Gulf of Biscay, Zumaia, Spain). J. Sedimet. Res. 69, 1253-1261.

Geyer, O., Pelleduhn, R., 1981. Sobre la estratigrafía y la facies espongiolítica del Kimmeridgiense de Calanda. Cuadernos Geol., Univ. Granada 10, 67-72.

Halley, R.B., Evans, C.C., 1983. The Miami Limestone: A Guide to Selected Outcrops and Their Interpretation. Miami Geological Society, Miami, FL (67pp.).

Harris, M.T., 1989. Facies anatomy and diagenesis of a Bahamian oolite shoal. Sedimenta 4, Comparative Sedi. Lab., University of Miami, 163pp.

Hine, A.C., 1977. Lily Bank, Bahamas: History of an active oolite sand shoal. J. Sediment. Petrol. 47, 1554-1581.

Kendall, C.G., Schlager, W., 1981. Carbonates and relative changes in sea level. Mar. Geol. 44, 181-212.

Leinfelder, R.R., 1993. Upper Jurassic reef types and controlling factors. Profil 5, 1-45.

Leinfelder, R.R., Nose, M., Schmid, D., Werner, W., 1993. Microbial crusts of the late Jurassic: composition, palaeoecological significance and importance in reef construction. Facies 29, 195-230.

Marsaglia, K.M., Klein, G.de V., 1983. The palaeogeography of Paleozoic ad Mesozoic storm depositional systems. J. Geol. 91, 117-142.

Meléndez, G., Aurell, M., Atrops, F., 1990. Las unidades del Jurásico superior en el sector nororidental de la Cordillera Ibérica: nuevas subdivisiones litoestratigráficas. Cuad. Geol. Ibérica 14, 225-245.

Pasquier, J.B., Strasser, A., 1997. Platform-to-basin correlation by high-resolution sequence stratigraphy and cyclostratigraphy (Berriasian, Switzarland and France). Sedimentology 44, 1071-1092.

Pérez-Urresti, I., Delvene, G., Meléndez, G., Ramajo, J., 1998. El Oxfordiense superior y la posición del límite OxfordienseKimmeridgiense en el sector de Tosos-Aguilón (Rama Aragonesa de la Cordillera Ibérica, España). Geogaceta 24, 185-188.

Price, G.D., Sellwood, B.W., Valdes, P.J., 1995. Sedimentological evaluation of general circulation model simulations for the "greenhouse" Earth: Cretaceous and Jurassic case studies. Sediment. Geol. 100, 159-180.

Rubin, D.M., McCulloch, D.S., 1979. Single and superimposed 
bedforms: a synthesis of San Francisco Bay and flume observations. Sediment. Geol. 26, 207-231.

Schlager, W., 1981. The paradox of drowned reefs and carbonate platforms. Geol. Soc. Am. Bull. 92, 197-211.

Scoffin, T.C., 1987. An Introduction to Carbonate Sediments and Rocks. Blakie, London (275pp.).

Tucker, M.E., Wright, V.P., 1990. Carbonate Sedimentology. Blackwell, London (482pp).

Valdes, P.J., Sellwood, B.W., 1992. A paleoclimate model for the Kimmeridgian. Palaeogeogr., Palaeoclimatol., Palaeoecol. 95, 47-72.

Walker, R.G., 1984. Shelf and shallow marine sands. Facies Models, Walker, R.G. (Ed.). Geosci. Can. Repr. Ser., Ontairo 1, 141-170.
Weissert, H., Mohr, H., 1996. Late Jurassic climate and its impact in carbon cycling. Palaeogeogr., Palaeoclimatol., Palaeoecol. 122, 27-43.

Wnendt-Juber, E., 1990. Das Korallenfürhrdende Kimmeridgium der nordwestlichen Iberischen Ketten und agenzender gebiete. Mikrofauna und -flora der korallenkalke. Paleontogr. Abt. A., Stuttgart 214, 79-120.

Wright, V.P., Burchette, T., 1996. Shallow-water carbonate environments. In: Reading, H.G. (Ed.). Sedimentary Environments. Processes, Facies and Stratigraphy Blackwell, London, pp. 325-394.

Wright, V.P., Faulkner, T.J., 1990. Sediment dynamics of Early Carboniferous ramps: a proposal. Geol. J. 25, 139-144. 